\title{
The Effects of Tillage-Induced Soil Disturbance on Weed Infestation of Winter Wheat
}

\author{
Zoltán Kende, András Sallai, Katalin Kassai, \\ Péter Mikó, Attila Percze, Márta Birkás* \\ Institute of Crop Production, Szent István University, \\ Gödöllő, 2100 Gödöllő, Hungary
}

Received: 3 August 2016

Accepted: 5 December 2016

\begin{abstract}
The purpose of this work was to investigate whether weed infestation and weed coverage could be managed using less non-inversion soil disturbance. The study was carried out in a degraded chernozem soil in a long-term trial where five ploughless tillage treatments were applied in addition to the mouldboard ploughing treatment: subsoiling, tine tillage (deep and shallow), disk tillage, and direct drilling. In this paper results of weed surveys are evaluated in winter wheat (Triticum aestivum L.) relation, since this crop was grown in six seasons inside of 14 years. Weed surveys were carried out four times in a season using the Balázs-Ujvárosi method, which is based on the ground coverage of the weeds. A high degree of weed coverage was found in the early years of the trial at the ploughless treatments, and particularly at the direct drilling system. During the six years of the wheat, weed coverage significantly decreased in all treatments, and the number of species also dropped from 18 to five. Weed coverage most often decreased in the order: direct drilling $>$ disking $>$ tine tillage (deep) $>$ tine tillage (shallow) $>$ subsoiling $>$ ploughing. We can conclude that the reasons for the decrease in weed coverage were the timing of tillage treatments, the high ratio of cereals in the crop sequence, and the timing of the chemical weed control application, once in the springs and second in cereal stubbles by the end of summer. Although data of grain yields of the winter wheat were supplementary to the evaluation of the changes in weed coverage, they were similarly connected with the tillage-induced soil condition. This study shows the possibility of the weed coverage decrease by the well-adopted soil tillage, including ploughless systems.
\end{abstract}

Keywords: weed survey, soil disturbance, ploughing, ploughless tillage, direct drilling

\section{Introduction}

In Hungary, the ploughing that is a primary tillage method has a long-term tradition. Moreover, soil inversion is believed to be the best weed control technique [1-2].

*e-mail: Birkas.Marta@mkk.szie.hu
There are statements in favour of ploughing that are for killing and burying the weeds, destroying emerged weed seedlings and restricting new seed production [3]. A plough may invert seeds deeper into the soil, where germination conditions are limited and seed dormancy has become longer [4]. This seems to be a critical point, while larger parts of the buried seeds can remain viable in soil for many years and only an insignificant proportion 
of the weed seed bank may be stimulated to germination by ploughing [5]. The role of ploughing in weed control seems to have slightly been changed by findings of recent trials [6]. Ploughing is found to be beneficial only if the regular tilled layer contains no or few weed seeds [7]. Initially, the increase in grass weed infestation hindered the introduction of ploughless tillage across Europe [8]. Authors have highlighted the original reason for the grass weed infestation, which is the weed seed accumulation effect of the former soil inversion technique [9-10].

Interpreting the effects of conservation tillage systems on weed infestation, however, assumes great caution. Mas and Verdú (2003) [9] noted that the lesser degree of soil disturbance under conservation tillage as compared with ploughing generally results in an increase in the occurrence of the weeds in any arable cropping systems. It is easy to understand that more weed seeds emerge and more quickly under soil conditions that are rather appropriate for seed emergence related to the conditions created by ploughing [11], thus providing a better opportunity for control.

The effect of mulch on weed infestation is found to be contradictory both in practice and in relevant literature [9, 12-13]. The use of straw mulch in dry soils can result in a significant suppression of weed density [14-15]. Weed germination may be limited by the blocking of the illumination of the soil surface and by allelopathic effects of the plant residues [9]. The trend of a gradual decrease was also observed in weed density and biomass in rainfed conditions, when there was an increase in the straw mulch rate [16-17]. However, more effective soil moisture conservation due to the effectual mulch cover may facilitate weed emergence even in dry seasons or in dry areas.

A little information was found concerning changes in weed coverage after multiple years of applying ploughless, adaptable tillage on degraded soil with high weed infestation. According to the definition, adaptable tillage improves or preserves the quality of the soil in harmony with ecological, climate, and farming requirements [18]. The current study was conducted to demonstrate whether adaptable tillage combined with a crop sequence adapted to the weed infested field circumstances could be suitable for decreasing weed coverage.

\section{Materials and Methods}

\section{Establish the Trial}

In accordance with the primary plan, the experimental area was selected in a wheat stubble field where soil had already been degraded. This degraded soil offered an opportunity for soil quality improvement by applying different adaptable tillage systems. To alleviate the selfseeding effect of wheat, white mustard (Sinapis alba L.) was sown after shallow stubble treatment. The majority of weeds emerging in late summer were suppressed by mustard with good results. The green mass of the mustard was chopped and, following the biomass wilting, the tillage treatments were performed.

The experiment was carried out in 2002 at the Experimental and Training Farm of Szent István University $\left(47^{\circ} 68^{\prime} \mathrm{N}, 19^{\circ} 60^{\prime} \mathrm{E}, 130 \mathrm{~m}\right.$ a.s.l.) near the town Hatvan, Hungary. The soil type is a Chernic Chernozem (WRB 2006), and its texture is a medium clay loam. The organic matter content of the upper $40 \mathrm{~cm}$ layer varies from $2.95 \%$ to $3.30 \%$. The mean soil $\mathrm{pH}$ value is $6.80(\mathrm{KCl})$. The average annual temperature at the site is $9.5^{\circ} \mathrm{C}$. The precipitation was measured at the weather station of the Training Farm. The multi-year average of the precipitation in wheat season is $435 \mathrm{~mm}$, which corresponds to water requirements of the wheat $(440 \mathrm{~mm})$ during a vegetation period. The amount of precipitation complied with the expected level only in two seasons (2005/06 and 2008/09; Fig. 1).

The experiment was arranged in a randomised block design with four replicates [25]. Total area of the experimental field is 5.772 ha $(312 \times 185 \mathrm{~m})$, including the field edge, and the area of each plot is $2,340 \mathrm{~m}^{2}$ $(13 \times 180 \mathrm{~m})$. Six treatments comprised deep $-\geq 0.3 \mathrm{~m}$ (that is subsoiling, L, ploughing, $\mathrm{P}$, and tine tillage, T) - , and shallow $-\leq 0.20 \mathrm{~m}$ (that is tine tillage, ST and disking, D) - soil disturbance along with direct drilling (DD). Primary tillage was applied in accordance with soil workability. Primary and secondary tillage were usually carried out in a single pass, just like seedbed preparation and drilling of winter wheat.

\section{Crop Management}

The crop sequence was planned for soil quality improvement and suppression of the weeds. Crops were sown from the start of the experiment: white mustard (2002), winter wheat (2002/03), rye (2003/04), pea (2004), w. wheat (2004/05), white mustard (2005), w. wheat (2005/06), phacelia (2006), maize (2007), sun-

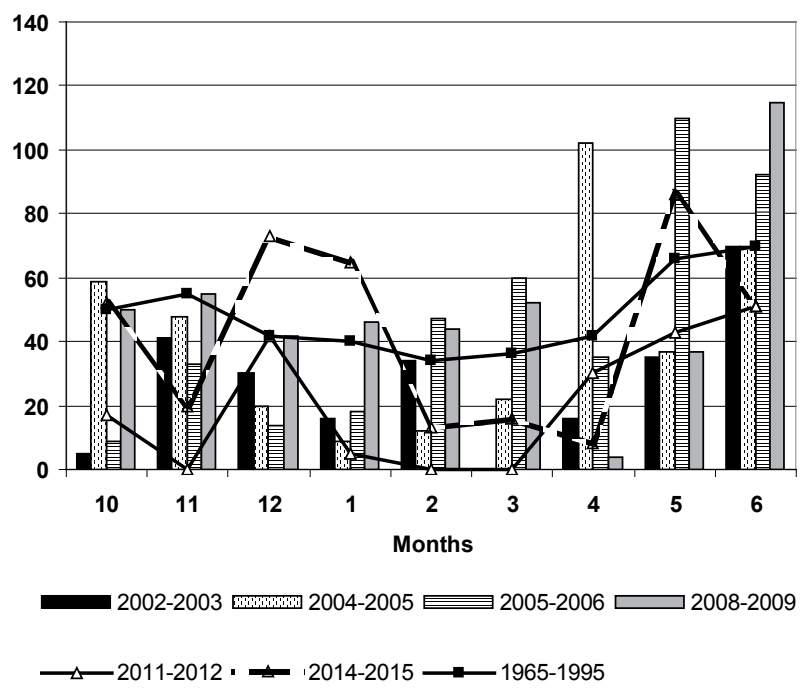

Fig. 1. Monthly cumulative precipitation amounts $(\mathrm{mm})$ for the six experimental years and for the 30-year period (1965-95). 
flower (2008), w. wheat (2008/09), white mustard (2009), maize (2010), oat (2011), w. wheat (2011/12), spring barley (2013), sunflower (2014), and w. wheat (2014/15), that is narrow-row crops dominate the sequence. Producing more cereals in the crop sequence was planned to take advantage of the weed suppression potential. The role of the white mustard, pea, and phacelia was to refresh the soil biological activity between two cereals. The wheat cultivars corresponded to the cultivars applied in the training farm relation. Domestic cultivar (Mv Verbunkos) was sown in the early years and a cultivar from Austria (Antonius) were sown lately. The area coverage ratio of winter wheat was assessed at the same time of the weed survey by the $2.0 \times 2.0 \mathrm{~m}$ quadrate device. The rate of fertilizer for winter wheat was moderate $-\mathrm{N} 120 \mathrm{kgha}^{-1}$, P $90 \mathrm{~kg} \cdot \mathrm{ha}^{-1}$, and $\mathrm{K} 70 \mathrm{~kg} \cdot \mathrm{ha}^{-1}$ - to avoid the higher impact of the optimal fertilization dose on the production circumstances.

Crop residues were used as organic matter source, and for that stalks were chopped and spread in a single course of the harvest. Agronomical data, including time and mode of stubble treatments of the preceding crops of the winter wheat, are summarized in Table 1. Time of herbicide treatments is also listed in Table 1 (besides the sowing and harvest time of the wheat). There was not any tillage procedure applied except for sowing at the direct drilling treatment.

\section{Weed Survey}

Weed surveys were carried out four times for winter wheat: 1) before the onset of the cold period (November); 2) in spring, before the application of chemical weed control (April/May); 3) at flowering (May/June); and 4) on the wheat stubble. Surveying the weed infestation, a scoring method was applied based on the measurement of the ground coverage of the weeds. The method, elaborated upon by Balázs and Újvárosi [19-20], is based on the estimation of the weed coverage and ranks the severity of the weed infestation by the percentage of the ground coverage. The scale of the Balázs and Újvárosi method is composed of eight main classes and 19 intermediate subclasses corresponding to the coverage ratio between 0.10 (negligible) and 100 (very strong). The marks of the main classes are as follows (with the relevant coverage ratio entered parenthetically): $0(0.1 \%),+(0.62 \%), 1(3.12 \%) 2$ (6.25\%), $3(12.50 \%), 4(25 \%), 5(50 \%)$, and $6(100 \%)$. The sub-classes, including intermediate values, provide a chance to survey more precisely the actual percentage of the weed coverage, e.g. $0-+$ scale corresponds to the coverage of $0.36 \%$, or $1-1-2$ scale to $3.90 \%$ or $3-4$ to the coverage per cent of $18.75 \%$. The Balázs-Ujvárosi method, considering its accuracy, has been widely used [1, 21-24], including the national weed surveys that were executed four times between 1947 and 1997 [22-23].

A wooden rectangular frame (a quadrate) placed on the ground is used during the weed survey process. Phases of the weed survey were as follows: 1) selection of the sampling places in five replications with an area of $2.0 \times 2.0 \mathrm{~m}$ in each experimental plot; 2) estimating the total weed coverage percentage of the sampling area; 3 ) listing the weed species occurring in the sampling area and estimating their coverage ratio; 4) adding the section data and comparing it to the data of the total coverage; 5 ) correcting and resurveying the coverage ratio of the weed species, as required; 6) coverage percentage of each weed species characterizing the soil tillage treatments as determined by the mean values of five replicates, and in the same way by the mean weed coverage ratio of the treatments.

\section{Statistical Analyses}

The effects of the different tillage treatments on weed coverage were analyzed separately each of the years of the experiment, using one-way ANOVA at a 0.05 level of significance. The mean total weed coverage and the wheat yield were evaluated with the single factor experiment series [25], where the years were used for repetitions. The least significant difference (LSD) at a significance level of

Table 1. Agronomical data for winter wheat for six years in the crop sequence.

\begin{tabular}{|c|c|c|c|c|c|c|c|}
\hline \multirow[b]{2}{*}{ Year } & \multicolumn{2}{|r|}{ Preceding crop } & \multicolumn{5}{|c|}{ Winter wheat } \\
\hline & Species & $\begin{array}{c}\text { Time and mode of stubble } \\
\text { treatment of preceding } \\
\text { crop }\end{array}$ & $\begin{array}{l}\text { Sowing } \\
\text { time }\end{array}$ & $\begin{array}{l}\text { Time of } \\
\text { herbicide } \\
\text { treatment }\end{array}$ & $\begin{array}{l}\text { Coverage ratio in } \\
\text { average of tillage } \\
\text { treatments }\end{array}$ & $\begin{array}{l}\text { Harvest } \\
\text { time }\end{array}$ & $\begin{array}{c}\text { Time and mode of wheat } \\
\text { stubble } \\
\text { treatment }\end{array}$ \\
\hline $2002-03$ & $\begin{array}{l}\text { White } \\
\text { mustard }\end{array}$ & 1 Sept., stalk chopping & 20 Nov. & 3 May & 81.05 & 16 July & - \\
\hline 2004-05 & Green pea & 31 Aug., stubble tillage & 4 Oct. & 16 May & 78.15 & 26 July & 31 Aug., stubble tillage \\
\hline $2005-06$ & $\begin{array}{l}\text { White } \\
\text { mustard }\end{array}$ & 5 Oct., stalk chopping & 12 Oct. & 19 April & 93.15 & 26 July & 31 July, stubble tillage \\
\hline 2008-09 & Sunflower & $\begin{array}{c}1 \text { Oct., stalk chopping and } \\
\text { stubble tillage }\end{array}$ & 15 Oct. & 8 May & 91.45 & 9 July & 9 July, stubble tillage \\
\hline 2011-12 & Oat & $\begin{array}{l}19 \text { July, stubble tillage; } \\
25 \text { Aug., chemical control }\end{array}$ & 17 Oct. & 4 May & 92.15 & 4 July & $\begin{array}{l}13 \text { Aug., } 24 \text { Sept., chemi- } \\
\text { cal control }\end{array}$ \\
\hline $2014-15$ & Sunflower & 25 Sept., stalk chopping & 8 Oct. & 30 April & 93.25 & 8 July & 15 Sept., chemical control \\
\hline
\end{tabular}


Table 2. Mean coverage ratio of weed species in winter wheat for six seasons inside of 14 years, the mean coverage ratio, and the number of frequency order in winter wheat fields stated by national weed surveys for 2008.

\begin{tabular}{|c|c|c|c|c|c|c|c|c|}
\hline \multirow[b]{2}{*}{ Weed species } & \multicolumn{6}{|c|}{$\begin{array}{l}\text { Mean coverage ratio of weeds in } \\
\text { the six years for winter wheat }\end{array}$} & \multicolumn{2}{|c|}{$\begin{array}{l}\text { Weeds in winter wheat fields } \\
\text { reported by the fifth (2008) } \\
\text { national weed survey }\end{array}$} \\
\hline & $2002-03$ & 2004-05 & $2005-06$ & 2008-09 & $2011-12$ & 20114-15 & $\begin{array}{l}\text { Mean coverage } \\
\text { ratio in national } \\
(\text { and in regional*) } \\
\text { relation }\end{array}$ & $\begin{array}{c}\text { Order of } \\
\text { dominance } \\
{[22]}\end{array}$ \\
\hline $\begin{array}{l}\text { Echinocloa crus-galli (L.) P. } \\
\text { Beauv. }\end{array}$ & 4.44 & 3.69 & 0.77 & 0.03 & 0.26 & 0 & $0.15(2.80)$ & 27. \\
\hline Bromus ssp. & 5.84 & 2.86 & 0.33 & 0.02 & 0 & 0 & $0.05(1.75)$ & 66. \\
\hline Setaria virdis (L.) P.Beauv. & 0 & 2.16 & 1.27 & 0.11 & 0.48 & 0 & $0.01(0.21)$ & 92. \\
\hline Stellaria media (L.) Vill & 0.53 & 2.54 & 0.61 & 0.13 & 0.42 & 0.07 & $0.56(1.06)$ & 11. \\
\hline Lamium purpureum L. & 0.82 & 2.75 & 0.82 & 0.10 & 0.47 & 0 & 0.08 & 38. \\
\hline $\begin{array}{c}\text { Capsella bursa-pastoris (L.) } \\
\text { Medik. }\end{array}$ & 0.41 & 0 & 0 & 0 & 0.20 & 0.08 & 0.39 & 14. \\
\hline Viola arvensis Murr. & 0 & 0 & 0 & 0.02 & 0.21 & 0.08 & 0.50 & 13. \\
\hline Anagallis arvensis $\mathrm{L}$. & 0.22 & 0 & 0 & 0 & 0 & 0 & 0.08 & 40. \\
\hline Fumaria schleicheri L. & 0 & 0 & 0 & 0 & 0 & 0.03 & 0.02 & 72. \\
\hline $\begin{array}{c}\text { Tripleurospermum perforatum } \\
\text { (Mérat) M.Lainz }\end{array}$ & 2.70 & 3.69 & 0.87 & 0.08 & 0.57 & 0.07 & $2.04(1.52)$ & 1. \\
\hline Chenopodium album $\mathrm{L}$. & 1.07 & 1.28 & 0.98 & 0.04 & 0.17 & 0 & $0.56(1.72)$ & 12. \\
\hline Chenopodium hybridum $\mathrm{L}$. & 0 & 0 & 0 & 0 & 0.20 & 0 & 0.04 & 57. \\
\hline Amaranthus retroflexus L. & 0 & 1.17 & 1.02 & 0.03 & 0 & 0 & $0.07(1.15)$ & 43. \\
\hline Datura stramonium $\mathrm{L}$. & 0 & 0.09 & 0 & 0 & 0 & 0 & $0.02(0.75)$ & 70. \\
\hline Polygonum aviculare L. & 0.45 & 0 & 0 & 0 & 0 & 0.01 & 0.36 & 15. \\
\hline Fallopia convolvulus (L.) A.Löve & 0.62 & 0.65 & 0.20 & 0.07 & 0.47 & 0 & $0.65(0.48)$ & 10. \\
\hline Cirsium arvense (L.) Scop. & 0.18 & 0 & 0 & 0 & 0 & 0 & $1.55(1.57)$ & 4. \\
\hline Convolvulus arvensis L. & 0.33 & 0 & 0 & 0 & 0 & 0 & $1.17(2.41)$ & 6. \\
\hline Total & 17.61 & 20.88 & 6.87 & 0.63 & 3.46 & 0.34 & & \\
\hline
\end{tabular}

*Data for county Heves where the experiment locates; no data from all weed species; 1-3: monocotyledonous, 4-18: dicotyledonous, 17-18: perennial weeds

$\mathrm{p}<0.05$ was used to identify differences between treatment means and completed using Fisher's adjustment [25].

The relationships between two factors, i.e., weed coverage and yield, was examined by the way of rank correlation [25]. The rank correlation coefficient measured the degree between the two rankings and examined the significance $(\mathrm{p}<0.05)$ of the relationship between them.

\section{Results and Discussion}

Weed Species and Weeds in the Frequency Order

During the six seasons within 14 years when winter wheat was produced, a total of 18 weed species were identified, of which three were monocotyledonous
(Table 2), with as many as 15 dicotyledonous. Sixteen of the surveyed weed species were annual and only two were perennial species. The perennial weeds were luckily no longer to be found in the experimental area from 2004. In addition, Table 2 presents the frequency number of the weed species on the basis of the latest (2007-08) nationwide weed surveys. The mean coverage ratio of the surveyed weeds is also listed in the table regarding both national and regional relationships. In addition to the list of weed species, Tripleurospermum perforatum was identified on the experimental site each year and the decrease of the coverage was a rather slow process. This may be the reason for the first position in the national weed frequency list. Bromus ssp. weeds are to be found relatively far down the national frequency list $\left(66^{\text {th }}\right)$, but it took more years to reduce the coverage ratio to a tolerable level. A summer annual weed, Fallopia convolvulus (that 
is the $10^{\text {th }}$ in the frequency list), emerged vigorously in cereal stubbles, and presumably the area requirements are met even in dry periods. The tolerance of the annual winter weed Viola arvensis was observed in the dry spring of 2015, all the more so because that has gradually expanded over the past 10 years (it was $13^{\text {th }}$ in the latest frequency list). In addition, another winter annual weed, Stellaria media (11 $1^{\text {th }}$ in the national list), was also found on the cereal stubbles at the end of the last summers. The presence of all three weeds (Fallopia convolvulus, Stellaria media, and Viola arvensis) was fairly incalculable in the last three years, which is likely to continue their higher infestation in the next growing seasons. Expansion of these weeds is presumably connected with the climate extremes in summers and end-summers. This assumption is harmonized to the findings from Peters et al. [26], who call attention to the climate-induced transformation of weed flora, the necessities of precise estimations of the damage potential of arable weeds, and, consequently, elaboration of effective management strategies.

\section{Trends in Weed Cover}

At the beginning of the experiment (in 2002), the mean weed cover of the preceding crop stubble reached a reasonably high (37.55\%) ratio due to the shortcomings of former land management practices, including weed control. Similar findings, obtained under different site circumstances, are widely discussed in the literature concerned [8-9, 14, 23, 27-28]. In addition, a higher weed infestation was expected in the experimental plots considering the dominance of the ploughless treatments. Therefore, selection of the crops to the long-term crop sequence was planned to taking advantage of the weed suppression potential. Šarūnaite et al. [29] claim that weed suppression is stated to be an important weed management solution; however, it depends on both the crops and productive crop densities.

The effects of tillage treatments, in fact the level of soil disturbance on the mean weed coverage ratio for six wheat seasons, are presented in Table 3. Tillage-induced soil disturbance had a significant effect on weed coverage percentage. However, this effect varied between seasons. In the first winter wheat season, the highest weed coverage (32.38\%) was surveyed on the plots of direct drilling (DD) and the lowest (4.38\%) in the ploughed soil (P). Weeds were grown with great area coverage in the tine-tilled $(17.59 \%$ and $19.04 \%)$ and disk-tilled (20.76\%) soils. We found, however, that a more vigorous weed growth is related to the good soil conditions that provided better opportunities for the control. Subsoiling (L), a technique improving the condition of the soil in the root zone, resulted during the first years in a higher ratio $(11.56 \%)$ of weed coverage than ploughing. However, that rate was significantly lower than the weed coverage for the other ploughless treatments. Three weed species were dominant in the first wheat season (Table 2), namely Bromus ssp., Echinochloa crus-galli, and Tripleurospermum perforatum, and their dominance can be connected with the former crop sequence. The higher weed coverage with noninversion tillage treatments compared to the ploughing system in the first years of the experiment concurs with previously published findings $[5,8]$.

Rye (Secale cereale L.) was produced in the second year of the trial, a crop that grows faster and tends to be more effective in weed suppression than wheat. However, pea (Pisum sativum L.) sown on rye stubble field enabled the survival of more weeds. The weed coverage after all of the applied treatments was higher (by 19\%) in the second winter wheat season as compared to the coverage ratio measured in the first season (Tables 2-3). The P treatment had the lowest weed coverage $(7.05 \%)$ again throughout the season, and the weed coverage was significantly higher (from $17.21 \%$ to $25.53 \%$ ) when moderated soil disturbance (L, ST, T, D) was applied. The DD treatment had the highest weed coverage $(30.91 \%)$, whose ratio differed significantly from values obtained at the other non-inversion treatments (Table 3). Adopting the rye in the second year of the trial concurs with results published by Pyšek et al. [30]. However, the secondary sown pea, as Mas and Verdú stated [9] in their paper, was incapable

Table 3. The effect of soil disturbance levels on the mean weed coverage ratio in six seasons, between 2003 and 2015.

\begin{tabular}{|c|c|c|c|c|c|c|c|}
\hline Tillage & $2002-03$ & $2004-05$ & $2005-06$ & $2008-09$ & $2011-12$ & $2014-15$ & Mean \\
\hline P & $4.38 \mathrm{a}$ & $7.05 \mathrm{a}$ & $6.12 \mathrm{a}$ & $0.19 \mathrm{a}$ & $13.56 \mathrm{c}$ & $0.19 \mathrm{a}$ & $5.25 \mathrm{a}$ \\
\hline $\mathrm{L}$ & $11.56 \mathrm{~b}$ & $17.21 \mathrm{~b}$ & $6.43 \mathrm{a}$ & $0.28 \mathrm{a}$ & $1.81 \mathrm{~b}$ & $0.19 \mathrm{a}$ & $6.25 \mathrm{~b}$ \\
\hline $\mathrm{ST}$ & $17.59 \mathrm{c}$ & $20.56 \mathrm{~b}$ & $7.05 \mathrm{a}$ & $0.36 \mathrm{~b}$ & $0.92 \mathrm{a}$ & $0.21 \mathrm{a}$ & $7.78 \mathrm{c}$ \\
\hline $\mathrm{T}$ & $19.04 \mathrm{~d}$ & $24.04 \mathrm{bc}$ & $6.53 \mathrm{a}$ & $0.46 \mathrm{bc}$ & $0.67 \mathrm{a}$ & $0.19 \mathrm{a}$ & $8.48 \mathrm{~d}$ \\
\hline $\mathrm{D}$ & $20.76 \mathrm{e}$ & $25.53 \mathrm{c}$ & $6.98 \mathrm{a}$ & $0.88 \mathrm{c}$ & $1.77 \mathrm{~b}$ & $0.30 \mathrm{~b}$ & $9.37 \mathrm{e}$ \\
\hline $\mathrm{DD}$ & $32.38 \mathrm{f}$ & $30.91 \mathrm{~d}$ & $8.13 \mathrm{~b}$ & $1.58 \mathrm{~d}$ & $1.97 \mathrm{~b}$ & $0.97 \mathrm{c}$ & $12.65 \mathrm{f}$ \\
\hline Mean & 17.61 & 20.88 & 6.87 & 0.63 & 3.45 & 0.34 & \\
\hline $\mathrm{LSD}_{0.05}$ & 1.49 & 3.73 & 1.15 & 0.12 & 1.27 & 0.10 & 0.36 \\
\hline
\end{tabular}

Fisher's least significant difference (LSD) test, $\mathrm{p}<0.05$. 
of weed suppression. We may remark that the mean area coverage of the Tripleurospermum perforatum reached the highest ratio (3.69) among the six wheat-cropping seasons. Bónis et al. and Smatana and Macák [1, 28] ranked this weed as the most frequent species in the wheat fields.

The preceding crop of the winter wheat was white mustard in the third (2005-06) wheat cropping season. The difference between the tillage treatments was insignificant in relation to the weed coverage percentage, presumably due to the suppressing effect of the secondary sown mustard. In contrast, the DD had significantly higher weed coverage $(8.13 \%)$ compared to the other treatments (between $6.12 \%$ and $7.05 \%$ ), where soil was disturbed to varying degrees. Difficulties in weed infestation that occurred in the first years have been noticeably reduced and the mean total weed coverage ratio has also dropped below seven (Tables 2-3). This finding is in harmony with the statements of authors $[14,31]$ who attributed the weed suppression effect to the narrow-row crops, including wheat and secondary cover crops.

During the 2008-09 season wheat followed sunflower (Helianthus annuus L.) where, fortunately, weeds failed to proliferate and therefore weed coverage continued to decrease in the wheat population as well (Table 3). The sunflower residues did not modify the weed cover at DD, while the volunteer seedlings that emerged in the autumn froze off during the winter. There was no significant difference found between weed coverage at the $\mathrm{P}$ and $\mathrm{L}$ treatments $(0.19 \%$ and $0.28 \%)$, but there were significantly proven differences between weed coverage percentages of these treatments and the S, T, D, and DD treatments.

The decrease in weed infestation turned slower during the next two years, first by abundant precipitation (1,189 mm from 1 October 2009 to 31 December 2010) and the deterioration of the conditions of the soils as a consequence of the rain stress and then by the extremely dry year of 2011. Grassy weeds that emerged in the wet period on maize fields were managed effectively by the post-emergence herbicide treatment. In 2011 springsown oat (Avena sativa L.) was grown, a crop known as an effective suppressor of weeds. Both mechanical and chemical weed control were applied in the oat stubble. In the case of the $\mathrm{P}$ and the $\mathrm{L}$ treatments there was a need for surface crumbling. The soil remained cloddy at the $\mathrm{P}$, the emergence of wheat was incomplete and due to the unexpectedly high weed population that emerged $(13.56 \%$, Table 3$)$. This result was proved the incalculable long-term effect of ploughing on weed infestation. Oat straw residues remained in place until the end of May at the $\mathrm{T}$, the ST, and the DD treatments, having positive impacts on the next yield and also on weed emergence, thanks to water conservation. A significant difference was found in terms of weed coverage between the treatments involving deeper (P, L, 13.56\% and 1.81\%) and shallower soil disturbances (ST, T, and D at $0.92 \%, 0.67 \%$, and $1.77 \%$, respectively) as well as DD (1.97\%). ZaniewiczBajkowska et al. [15] found significantly smaller weed infestation where straw mulch was left until the time of cabbage harvest.

In 2014-15 winter wheat was sown after sunflower (Helianthus annuus L.), in which soil surface remained sufficiently free of weeds. The average weed coverage ratio in winter wheat was low $(0.34 \%$, Tables $2-3)$. There were no significant differences in terms of weed coverage between the $\mathrm{P}, \mathrm{L}, \mathrm{ST}$, and $\mathrm{T}$ treatments (coverage ratio was between $0.19 \%$ and $0.20 \%$ ), but there were significant differences between these treatments and the $\mathrm{D}$ as well as between D $(0.30 \%)$ and DD $(0.97 \%)$. The number of weed species also dropped.

The process of decreases in weed coverage followed a predictable trend during the six seasons when winter wheat was grown in the experimental area. Weed cover was found to be the lowest on the ploughed soil and the second lowest on the subsoiled soil in five seasons, while the highest weed coverage (also in five seasons) was found on the undisturbed soil (DD). The effect of tine tillage on weed coverage was acceptable due to the good weed emergence, which gave the chance for effective control. Weed coverage most often decreased in the order: direct drilling $>$ disking $>$ tine tillage $($ deep) $>$ tine tillage (shallow) $>$ subsoiling $>$ ploughing.

There was one year (2011-12) from the six wheat cropping seasons when the seedbed after ploughing was consequently poor, and the stock density of the winter wheat also became poor. For this reason the weed coverage reached the highest ratio $(13.56 \%)$ of the season at the ploughing treatment. The unforeseen incident was staggered by the classic statement in the weed-reducing role of ploughing. It is consistent with the findings and comments of Dang et al. [11], who pointed to the risks in weed management burying the viable weed seeds. The results of the weed survey supported once more the role of soil condition for achieving an optimal stock density of the wheat, and through this attaining the weed-suppressing effect of the crop.

The decrease in weed infestation and the magnitude of coverage throughout the experiment was attributed to the timing of the chemical weed control application - once in the spring and the second in cereal (wheat, oat) stubbles by the end of summer. This is consistent with the findings of Nakamoto et al. [17] and Gruber et al. [32], who suggested capable solutions for reaching or maintaining a tolerable weed infestation level in case of reduced soil disturbance. Chemical weed control on the cereal stubbles was an additional solution for maintaining limited coverage of weeds by the end of summer. In their studies, Boström [3] and Gruber et al. [32] revealed the importance of stubble management if needed to reduce weed infestation, mainly dicotyledonous species.

\section{Wheat Yield}

The type and degree of soil disturbance had significant effect on the yields in all seasons, but its effects varied between years (Table 4). The deeper loosened layers produced a higher yield in the first year (2002-03), probably 
Table 4. The effect of soil disturbance on the main grain yield of winter wheat (tha $\left.{ }^{-1}\right)$ between 2003 and 2015.

\begin{tabular}{|c|c|c|c|c|c|c|c|}
\hline Tillage & $2002-03$ & 2004-05 & $2005-06$ & 2008-09 & 2011-12 & $2014-15$ & Mean \\
\hline $\mathrm{P}$ & $3.12 \mathrm{e}$ & $7.53 \mathrm{~d}$ & $4.59 \mathrm{c}$ & $5.59 \mathrm{e}$ & $1.23 \mathrm{a}$ & $5.70 \mathrm{~b}$ & $4.62 \mathrm{f}$ \\
\hline $\mathrm{L}$ & $3.41 \mathrm{f}$ & $5.81 \mathrm{c}$ & $4.58 \mathrm{c}$ & $5.78 \mathrm{~d}$ & $1.61 \mathrm{~b}$ & $5.76 \mathrm{~b}$ & $4.49 \mathrm{e}$ \\
\hline ST & $2.51 \mathrm{~b}$ & $4.76 \mathrm{~b}$ & $3.07 \mathrm{~b}$ & $5.57 \mathrm{c}$ & $2.01 \mathrm{c}$ & $5.77 \mathrm{~b}$ & $3.95 \mathrm{~b}$ \\
\hline $\mathrm{T}$ & $2.99 \mathrm{~d}$ & $4.67 \mathrm{~b}$ & $3.97 \mathrm{c}$ & $5.02 \mathrm{a}$ & $3.00 \mathrm{~d}$ & $5.73 b$ & $4.23 \mathrm{~d}$ \\
\hline $\mathrm{D}$ & $2.76 \mathrm{c}$ & $4.83 \mathrm{~b}$ & $3.63 \mathrm{~b}$ & $5.48 \mathrm{~b}$ & $3.18 \mathrm{e}$ & $4.71 \mathrm{a}$ & $4.10 \mathrm{c}$ \\
\hline DD & $1.10 \mathrm{a}$ & $1.81 \mathrm{a}$ & $1.36 \mathrm{a}$ & $6.03 f$ & $3.84 \mathrm{f}$ & $4.82 \mathrm{a}$ & $3.16 \mathrm{a}$ \\
\hline Mean & 2.64 & 4.90 & 3.53 & 5.57 & 2.48 & 5.42 & \\
\hline $\mathrm{LSD}_{0.05}$ & 0.22 & 1.30 & 0.60 & 0.043 & 0.28 & 0.58 & 0.13 \\
\hline $\begin{array}{l}\text { Type of the } \\
\text { season }\end{array}$ & dry & average & average & average & dry & rainy & \\
\hline
\end{tabular}

Fisher's least significant difference (LSD) test, $\mathrm{p}<0.05$

which was connected with the alleviation of the existing soil compaction, and average wheat yield improved in the order of $\mathrm{DD}<\mathrm{ST}<\mathrm{D}<\mathrm{T}<\mathrm{P}<\mathrm{L}$. Although the average of yield level remained low $\left(2.64,4.9\right.$, and $\left.3.53 \mathrm{tha}^{-1}\right)$ in the first three wheat seasons), at this time the ratio of the weed coverage showed a fairly high ratio (Table 3 ). The yield of winter wheat in the micro region, at moderated fertilization levels, may reach about 5 tha $^{-1}$ in the case of optimal growing circumstances, including precipitation, tillage, and crop protection. Moreover, in dry years (in 2003 and 2012) the average yield of winter wheat was poor ( 3.5 tha $^{-1}$ or less) in the micro region, related to the low amount of precipitation (Fig. 1). In the second dry season (2011-12) average yield increased in order of $\mathrm{P}<\mathrm{L}<\mathrm{S}$ $\mathrm{T}<\mathrm{T}<\mathrm{D}<\mathrm{DD}$, which is the sequence of the treatments after their significant change in ranking compared to the first season. The difference between the lowest (P, 1.23 tha $\mathrm{th}^{-1}$ ) and the highest (DD, $3.84 \mathrm{tha}^{-1}$ ) yield reached a value of 2.61. However, the ratio of weed coverage on the ploughed soil was seven times higher compared to the DD treatment. The soil quality development for the T, ST, and L treatments probably contributed to producing a reasonable level of wheat yields (5.73-5.77 tha $\left.{ }^{-1}\right)$ in the sixth growing season. At this time wheat yield decreased in the order: tine tillage ( shallow) $>$ subsoiling $>$ tine tillage (deep) $>$ ploughing $>$ direct drilling $>$ disking. There was low difference in wheat yield between P, L, ST, and T treatments (Table 4), and similarly in weed coverage ratio (Table 3). Dang et al. [11] claimed to apply reduced long-term soil disturbance in order to achieve and maintain the complex advantages of this mode, which is soil preservation, acceptable yield, reduced weed infestation, etc. Sime et al. [14] and Mas and Verdú [9] highlighted that the decrease in weed infestation could be a parallel solution with soil condition improvement.

The gradual reduction of weed coverage also positively affected the mean yields of winter wheat. The calculation by rank correlation confirmed a probable coherence between weed coverage and wheat yield $(r=0.89>0.81)$ at a $(\mathrm{p}<0.05)$ level of significance.

\section{Conclusions}

There were negative and positive factors both influencing weed coverage at the current experimental conditions. The negative factors were given at the start of the experiment, namely the degraded soil, the high weed infestation, and the unpredictable climate. The positive factors of the experiment were the crop sequence adapted to the unfavourable soil conditions and to the high weed infestation, the promotion of weed emergence, and then applying well-timed weed control. While the influence of climate extremes on weed population is considered to be inevitable, an effective weed control strategy may be the key factor for managing this evergreen problem.

In the current experiment weed emergence was appropriate under good soil conditions created by L, ST, and $\mathrm{T}$ treatments and provided the opportunity for control. The results have shown that a decrease in weed coverage should also be managed by the direct drilling system. We may conclude that the adaptable tillage may have a competitive advantage on weed coverage not only by ploughing but by ploughless systems as well. Future study is needed to investigate the coherence between adaptable soil disturbance, weed coverage in wide row crops, and sustainably improve the crop yields through soil quality development.

\section{Acknowledgements}

This study was supported by the research project AGRARKLIMA.2 VKSZ_12-1-2013-034 funded by the National Research, Development, and Innovation Office. We would like to express our great appreciation to the management of Hatvan-Józsefmajor Training Farm. 


\section{References}

1. BÓNIS P., BALÁZS F., BALÁZS J., KISMÁNYOKY T. Acta Agr. Hun., 58, 69, 2010.

2. PERCZE A. Weed survey in winter wheat grown in a longterm soil cultivation experiment carried out on brown forest soil in Gödöllő. Növénytermelés, 51 (1), 97, 2002 [In Hungarian].

3. BOSTRÖM U. Type and time of autumn tillage with and without herbicides at reduced rates in southern Sweden 1. Yields and weed quantity. Soil Till. Res., 50, 271, 1999.

4. BØRRESEN T., NJØS A. The effect of ploughing depth and seedbed preparation on crop yields, weed infestation and soil properties from 1940 to 1990 on a loam soil in south eastern Norway. Soil Till. Res., 32, 21, 1994.

5. OZPINAR S. .Effects of tillage systems on weed population and economics for winter wheat production under the Mediterranean dryland conditions. Soil Till. Res., 87, 1, 2006.

6. HAN H., NING T., LI Z. Effects of tillage and weed management on the vertical distribution of microclimate and grain yield in a winter wheat field. Plant, Soil Env., 59, 201, 2013.

7. COLBACH N., BUSSET H., ROGER-ESTRADE J., CANEILL J. Predictive modelling of weed seed movement in response to superficial tillage tools. Soil Till. Res., 138, 1, 2014.

8. MELANDER B. A review of the major experiences with weeds in non-inversion tillage sytems within the European Economic Community (EEC). Chapter in: Tebrügge F., Böhrsen A. (Ed.) Experience with the applicability of notillage crop production in the West-European countries. Review Papers and Conclusions. Fachverlag Köhler, Giessen, 63, 1998.

9. MAS M.T., VERDÚ A.M.C. Tillage system effects on weed communities in a 4-year crop rotation under Mediterranean dryland conditions. Soil Till. Res., 74, 15, 2003

10. McCLOSKEY M., FIRBANK L.G., WATKINSON A.R., WEBB D.J. The dynamics of experimental arable weed communities under different management practices. Veg. Sci, 7, 779, 1996.

11. DANG Y. P., MOODY P. W., BELL M.J., SEYMOUR N. P., DALAL R. C., FREEBAIRN D. M., WALKER S. M. Strategic tillage in no-till farming systems in Australia's northern grains-growing regions: II. Implications for agronomy, soil and environment. Soil Till. Res., 152, 115, 2015.

12. DVOŘÁK P., TOMÁŠEK J., HAMOUZ K., KUCHTOVÁ, P. Reply of mulch systems on weeds and yield components in potatoes. Plant, Soil Env., 61, 322, 2015.

13. MOHLER C. L., GALFORD A.E. Weed seedling emergence and seed survival: separating the effects of seed position and soil modification by tillage. Weed Res., 37, 147, 1997.

14. SIME G., AUNE J.B., MOHAMMED H. Agronomic and economic response of tillage and water conservation management in maize, central rift valley in Ethiopia. Soil Till. Res., 148, 20, 2015.

15. ZANIEWICZ-BAJKOWSKAA., FRANCZUK J, KOSTERNA E. Direct and secondary effects of soil mulching with straw on fresh mass and number of weeds, vegetable yield. Pol. J. Environ. Stud. 18, 1185, 2009.
16. DIN S., RAMZAN M., KHAN R., RAHMAN M., HAROON M., KHAN T.A., SAMAD A. Impact of tillage and mulching practices on weed biomass and yield components of maize under rainfed condition. Pakistan J. Weed Sciences Res., 19, 201, 2013.

17. NAKAMOTO T., YAMAGISHI J., MIURA F. Effect of reduced tillage on weeds and soil organisms in winter wheat and summer maize cropping on Humic Andosols in Central Japan. Soil Till. Res., 85, 94, 2006.

18. BIRKÁS M. Tillage, impacts on soil and environment. Chapter in: Glinski J., Horabik J., Lipiec J. (Ed.) Encyclopedia of Agrophysics. Springer Dordrecht, 903, 2011.

19. BALÁZS F. A new method for application of the plant coenological survey. Botanikai Közlemények, 41, 18, 1944 [In Hungarian].

20. ÚJVÁROSI M. The weeds of the Hungarian arable fields and their life form analysis. 2, 237, 1952 [In German].

21. BORSICZKY I., ENZSÖL E., FARKAS B., REISINGER P. Study of the use of N sensor in weed covered fields of winter wheat. Herbologia, 15 (1), 99, 2015.

22. NOVÁK R., DANCZA I., SZENTEY L., KARAMÁN J. The Fifth National Weed Survey in Arable Lands of Hungary 2007-2008. Ministry of Agriculture and Rural Development, Budapest, 367, 2011 [In Hungarian].

23. REISINGER P. Weed flora survey of the agricultural lands in Hungary (1947-2000). Magyar Gyomkutatás és Technológia, 2, 65, 2001.

24. REISINGER P., KÖMIVES T., NAGY S. Sampling site density in weed surveys for precision weed control. Növényvédelem, 39 (9), 413, 2003.

25. SVÁB J. Biometrical Methods in Research Work (3rd Ed.). Mezőgazdasági Kiadó, Budapest, 1981 [In Hungarian].

26. PETERS K., BREITSAMETER L., GEROWITT B. Impact of climate change on weeds in agriculture: a review. Agron. Sust. Dev., 34, 707, 2014.

27. BIRKÁS M., SZALAI T., GYURICZA C., GECSE M., BORDÁS K. Effects of the disk tillage on soil condition, crop yield and weed infestation. Rostl. Vyr., 48 (1), 20, 2002.

28. SMATANA J., MACÁK M. Weed infestation dynamics of winter wheat fields in South-Western Slovakia. Res. J. Agr. Sci., 46 (2), 338, 2014

29. ŠARŪNAITĖ L., DEVEIKYTĖ I., ARLAUSKIENĖ A., KADŽIULIENĖ Ž, MAIKŠTĖNIENĖ S. Pea and spring cereal intercropping systems: Advantages and suppression of broad-leaved weeds. Pol. J. Environ. Stud., 22, 541, 2013.

30. PYŠEK P., JAROŠÍK V., KROPÁČ Z., CHYTRÝ M., WILD J. \& TICHÝ, L. Effects of abiotic factors on species richness and cover in Central European weed communities. Agriculture, Ecosystems and Environment, 109, 1, 2005.

31. WINKLER J., CHOVANCOVÁ S. The effect of precipitation on weed infestation of spring barley under different tillage conditions. International Journal of Biological, Food, Veterinary and Agricultural Engineering. 8, 844, 2014.

32. GRUBER S., PEKRUN K., MÖHRING J., CLAUPEIN W. Long-term yield and weed response to conservation and stubble tillage in SW Germany. Soil Till. Res., 121, 49, 2012. 